PEOPLE: International Journal of Social Sciences

ISSN 2454-5899

Gordon E Zhang, 2021

Volume 7 Issue 3, pp. 59-81

Received: 13 th August 2021

Revised: 27th November 2021, 10 th December 2021

Accepted: 14 $4^{\text {th }}$ December 2021

Date of Publication: 17th December 2021

DOI- https://doi.org/10.20319/pijss.2021.73.5981

This paper can be cited as: Gordon. A. F. R. E Zhang, Q. (2021). The Evolution of Colonial Legacy and Social Status of Women, A Case Study of Egypt between 1952-2016. PEOPLE: International Journal of Social Sciences, 7(3), 59-81.

This work is licensed under the CreativeCommons Attribution-NonCommercial 4.0 International License. To view a copy of this license, visit http://creativecommons.org/licenses/by-nc/4.0/ or send a letter to Creative Commons, PO Box 1866, Mountain View, CA 94042, USA.

\title{
THE EVOLUTION OF COLONIAL LEGACY AND SOCIAL STATUS OF WOMEN, A CASE STUDY OF EGYPT BETWEEN 1952-2016
}

\author{
Ruth Frimpomaa Anarfi Gordon \\ Zhengzhou University, School of History, Zhengzhou City-45001, Henan-province, China \\ frimpomaagordon84@gmail.com \\ frimpomaaafia@yahoo.com \\ Qianhong Zhang \\ Zhengzhou University, School of History, Zhengzhou City-45001, Henan-province, China \\ Zhangqhzd@163.com
}

\begin{abstract}
The topic of female's rights and gender equality is an issue of the Arab uprisings call for democracy. In the Arab Muslim-majority nations, some creeds have influenced the impact of the gender discussion. Namely Islamic teaching and local cultural practices about females' duties in a culture in the Arab world: Western, European colonial perceptions of the rights of females, as well as ultimately policy reforms that are gender-related nationwide. The study aims to look at the situations (gender inequality) of women 11. in the Arab world before and after colonization, with a focus on Egypt. The impact of colonial heritage on women's formal and higher education as well as recent gender practices in the public sphere, the responses from the global actions taken, and response from the national level regarding females' rights. This research used the descriptive approach relying on literature from publications, presented
\end{abstract}


papers, journals, books, and useful websites to focus on the topic. It also examines the parallels and variations in gender parity reform strategies in Egypt. However, part of the findings is that women's abilities have been deliberately relinquished to the back and downplayed by society.

\section{Keywords}

Women's Education, Feminism, Gender equality, Social change, Colonial Legacy

\section{Introduction}

After the Ottoman Empire collapsed during World War I (WWI), Lebanon, Algeria, Morocco, and Syria got colonized and secured by France (O’Donnell, Abu-Lughod, \& AbuRabia, 2021). Egypt, Jordan, Palestine, and Iraq were under British control, while Libya was under Italian control (Sezgin, 2013). Education within the Middle East and North Africa (MENA) was limited to the European colonizers, who were a key staff of the government and their relations' administration under the colonial rule, while a substantial number of religious institutions remained largely intact in the region (Megahed \& Lack, 2011). As some of the Middle East and North African nations gained freedom, an establishment framework about religious establishments coupled with the colonial educational structure served as a basis for the standard educational system to evolve (Marshall, 2008). The 2008 report of the world bank stated that early changes in the 1950s and 1960s faced a challenge in incorporating old and modern structures (World Bank Report, 2008).

However, Egyptian leaders after independence and their Turkish nationals regarded education as an intellectual instrument in the national movement, according to (Allam \& Newman, 2018). After the 1953 revolution, Gender reform policies have been used by reform movements, to win women's support in Egypt. According to Amar (2011), Educational Gender parity started to decrease in the late 1930s and the early 1940s, as traditional female domestic roles were reaffirmed. Many newly independent governments 40. supported empowerment and gender equality from the 1950s through to the 1970s as a section of their attempts to frame modern civil identification (El-Safty, 2004). It is against this grounding that this study seeks to establish how colonial legacies have shaped the status of women from the period 1952 to 2016.

\subsection{The Historical Development in Egypt}

This section gives an overview of ancient Egypt, which coincide geographically nearly to contemporary day Egypt in the north-eastern part of Africa. The most unique feature for both ancient and modern Egypt that has attracted the attention of the world over the years is the River Nile. It is one of the great and famous rivers in the world and it is directly opposite 
the Amazon River. The Nile River flows from the Eastern Mid-Africa up into the Mediterranean Sea, due to the flow of the North fertile soil and fresh waters for agriculture.

The Nile River fertile bank, its delta, and Egyptian native inhabitant accomplishments and outside influence played a role in Egyptian wealth history (Berman, Shapira, \& Ben-Jacob, 2015; Compbell \& Rogers, 2007). Ancient Egypt remained a mystery till the Rosetta Stone was found and translated. One of the seven wonders of the ancient world was The Great Pyramid of Giza in Egypt and for decades, the Alexandria library operated as the only one of its sorts. Egypt has one of the oldest human buildings, dating back to about 100,000 BC (Berman et al., 2015). About 3150 BC, the civil union of the lower and upper Egypt brought together ancient Egyptian society. Narmer, the first Dynasty of Pharaoh, was in power at the time. Ptolemy Soter I, one of the former generals, overthrew the Achaemenid Empire and founded the Hellenistic Ptolemaic State, which lasted until the conquest by the Achaemenid Empire (Jacob, 2011).

Constant foreign and civil wars among Ptolemaists, as well as native revolt, resulted in the defeat of the kingdom eventually annexation by Rome. After Cleopatra's death, one of the colonies of the Roman Empire was Egypt, ending its nominal independence (Sezgin, 59.2013). Around 5000 years ago, the independent countries along the Nile River formed a kingdom ruled by a king called Pharaoh. Due to their joining together and interaction of various cultures, a different new culture was birthed (Tyldesley, 2012). Egypt was the most dominant nation in the Mediterranean for nearly three centuries. Alexander the Great's arrival in Egypt in 332 BC marked a turning point in Egyptian culture and life. In no time, the unique culture formed got eroded and was replaced by the Greeks, Romans, and Arabic traditions. As a result of the new emergence, Egypt lost the worth of its past practices and traditions (Tyldesley, 2012). The stone monuments and hieroglyphic writings serve as evidence that the Egyptians once had a culture. After 2000 years, there is an effort to decode the hieroglyphic handwriting, and the study of ancient Egypt is blossoming within institutions. At the same time, the study of ancient Greeks and Latin was fading from the curriculums. Egyptian cultural value preservation sites such as Museums are full of local and foreign visitors who desire to learn more about the culture (Tyldesley, 2012). Such was a period of restoring and adding strength to Egyptian history and early life.

\subsection{Ancient Egypt and Social Status of Women}

Egypt is a country located along the Nile River Valley in the Northern part of Africa. Ancient Egypt was famous in the Mediterranean world between 3100 BC and 332 BC. People in ancient Egypt highly valued families (Kemp, 2018). The country was intricate and 
captivating in civilization (Kemp, 2018). According to researchers, it is easy to study the history of Egypt than any other history (Assmann, 2003; Shaw, 2003) because the Egyptians were able to record their history in detail. Due to their records, the Egyptians were religious ahead of their time due to technological and economic breakthroughs.

Ancient Egypt was the innovator of the time, hence the most influential nation for over three thousand years. Being located along the Nile River, it was proud of its rich culture, strong leaders, the source of so much wealth, and hierarchical society. It was the most powerful and innovative nation. According to Mikhail (2011), ancient Egypt arose as an independent civilization and became one of the most influential nations in human knowledge, science, and religion. Studies showed that Pharaoh was the supreme leader for both the government and religion (Mikhail, 2011). However, the ancient Egyptian golden age was characterized by a succession of prosperous kingdoms interspersed with periods of relative insecurity. The ancient kingdoms of the early bronze old, middle bronze, and late bronze new kingdoms were among the stable age kingdoms. With the rise of the Nubia ruling kingdoms, men had no option of choosing careers of their interest as they inherited jobs from their fathers.

Women's status and significance varied according to culture and age. Some communities had a predominantly matriarchal culture, while others had patriarchal culture. Women's roles in ancient Egypt and their ability to rise to positions of authority evolved during the Early Dynastic Period on women's status (c. 3000 BCE). On the contrary, Egyptians had a specific outlook on women in the first and second transitional eras (2100 97.BCE-150 BCE), the new empire (Kingdom, 1550 BCE-1200 BCE), as well as most predominantly the Ptolemaic era (300 BCE-30 BCE). In terms of legal rights, Herodotus' evaluation of Egypt, since the farthest opposite of Greece was not inaccurate. Women had little constitutional rights and were required to nominate one man to act in their place in court or other legal matters. Upper-class women had even more rights until the Ptahhotep era (2686-2181 BC), when they managed to defend themselves in the court of law on their own and control lands, free slaves, prosecute or sue others and even file for divorce. Educated or noblewomen and men were equally essential in the eyes of the law.

In contrast to western norms, marriage and divorce proceedings, for example, were more egalitarian. A husband and wife were the most common family unit. Premarital sex was socially acceptable before a wedding, and divorce was never an issue. Women who had divorced regained their dowries and lands. These privileges were only open to upper-class women; lower-class women were not entitled to them. The Egyptian constitution was neutral to gender issues, according to (Crippa \& Cucut, 2020). In ancient Egypt, a social status 
determined legal status, the patriarchal structure in ancient Egypt had total power over women's social status, with her father controlling her status when she was unmarried and her husband controlling her status after she married. Women's emancipation was suggested to be connected to a male counterpart somewhere down the road. Those with considerable wealth could engage in the government, as well as becoming a priestess, or sitting on a jury, unlike women married to rule and steer the affairs of their homes.

Lower-class women had more access to the public domain than upper-class women due to necessity; they tilled the land for farming, made textiles, worked domestically as servants and also worked on sites and buildings, etc. On the other hand, some women of the lower class took the job of entertainers to entertain the royal household, while men filled all artisan jobs. Interestingly, ancient Egyptian society became an exciting combination of the hodgepodge of women's progressive rights around restrictions. Nevertheless, the development of Egypt's transformation in the past decades was governed by Pharaoh. He was also seen as the god of the land, he was worshipped and was in control of the army. Most societies of the ancient world were peasant farmers of the vast population. Pharaoh or one of the temples' officials, both of which were extremely rich, owned the land. In Egyptian culture, women seem to have held a similar role. They could buy and sell land, enter into contracts, marry and divorce, inherit, and go to court to settle legal disputes, just like men. Land ownership by married couples was likely. As high priestesses, some women had a lot of influence, but Public office was exclusively for men in almost all ancient societies (Htun \& Weldon, 2018).

Egyptians had the avenues to free education and healthcare in the United Arab republic before 1952. Furthermore, graduates would be assured jobs. The social welfare system at the time was fragile to elevate the majority of the population, and non-governmental efforts in the area of welfare were seldom, and the division of gender roles was by labour. Women's work (household chores and childbearing) contributed significantly in the public sphere to productive work, mostly in cities. Most inputs were underestimated since a number of them worked in the informal sector. Relatively, women and men, in general, had equal rights legally. For instance, the fair legal concept of remuneration is only regarded in the public sector, so women working in the informal sphere usually get less pay than men. In personal status law, women did not have many rights as men (divorce, child custody, marriage, etc). On the other hand, men had the right to pass on Egyptian citizenship to their children in most countries (Mahmood, 2015). 


\subsection{Women and Gender Roles During Colonial Period}

Colonialism and gender have a complicated relationship that has a reciprocal effect. Gender redefined imperial rule's borders on systems and concepts of femininity and masculinity were reshaped by colonialism and globalization, according to colonial texts and histories.

Through gender relations and representations, an empire's systems and institutions were upheld and structured. Reading colonialism through the lens of gendered distinction clarifies the complexities of these terms while also exposing the colonial order's limitations and flaws. This ingress delves into the textual, material, and theoretical aspects of colonialism key texts that have influenced our understanding of the dynamics of the relationship. African men and women were entitled to their ethnic duties during this period, but the majority of African tribes were influenced by European culture as a result of imperialism. During this period, women were predominantly considered homemakers and played nurturing roles. They acted as men's partners and exchanged agricultural products. Women were degraded to the bottom of the postcolonial social and economic pyramid, losing their economic and social influence and returning to food production while men received wages. According to Tucker (1985), In the nineteenth century, there was a lot of social and economic change that the Egyptians experienced as the country's increasing diplomatic links with Europe. Women who were peasants in the fields, craftsmen, and petty traders transformed their work positions as their family lives, concentrating on lower-class women. During Egypt's colonial era, women's positions were focused on the shoulders of a few individuals. The recommendation was that women did not have total ownership or access to land. During Egypt's colonial era, women's positions were concentrated in 166. hands of a few individuals. It was suggested that women did not have total ownership or access to land. Women in this period lacked the legal right to own land in the free market, meaning that they were not economically self-sufficient, forcing them to work in the agricultural sector.

\subsection{Colonial Legal Legislation on Women in Egypt}

Egypt has signed many international treaties relating to the same human right and separation. However, the domestic court's defence of equality and discrimination rights falls short of international standards. As the constitution guarantees equality and forbids discrimination, the right's scope was limited to the lack of comprehensive description under international law. The state did not pass comprehensive equality law but did pass one particular law that recognized the interests of a community that was discriminated against. Provisions were affecting the rights of people with disabilities that were incompatible with international 
law. In addition, a variety of clauses in various areas of law aimed at ensuring equality and non-discrimination complement the Constitution's safeguards. This patchwork of antidiscrimination safeguards falls short of international law's criteria. Judicial pluralism was a scheme of separate legal orders conceived for different persons in Egypt. Egypt's legal framework provided equal rights and responsibilities for all people while the western and the personal law of Islam were upheld. In all these, Egypt demonstrated the difference between dual legal systems. In 1980, the Egyptian constitution proclaimed Islam as similar religion. It was revised to consider Islamic jurisprudence as the source of law. Personal standing or status law (also seen or known as "family law") was the only field of law in which Sharia was regarded as the primary source of legislation (Beck, Jenks, Keddie, \& Young, 1979).

The civil law of France underpins the bulk of Egypt's legal system. Personal status law recognizes "what distinguishes one person from another" in terms of natural and familiar features, and considers the law's legal impact on social life. This same law, which regulated marriage, divorce, and inheritance among other things, defined the status of women in Egypt. Secular courts of judges educated along western jurisprudential lines dealt with legal problems that fall beyond the personal status field. Given the importance of personal status in deciding one's social life, no formal code regulating family rights has yet to be enforced. In this regard, however, the Egyptian legislature passed a variety of significant laws.

\subsection{The Status of Women in the Arabian Peninsula}

Women have historically had lower social status than men in most societies around the world. They constitute half of the world's population and so increasing their ignorance will mean denying a nation the benefits of the capabilities of half that populace with repercussions that are negative and obvious.

It is the cultures and social norms of society that put men above women in the hierarchy. Many discussions about gender roles and equality in society took taking place at that moment. As a result, CEFAS researchers, led by Tuchscherer, agreed to conduct a study to determine the condition of gender in the Arabian Peninsula (Comer, 2012). The research sought to seek how women in societies and organizations have risen to prominence in recent years to campaign for their rights, and the reality seems to be in the enlightenment age. This study discovered that data on women in the Arabian Peninsula was scarce. Several continents around the world are witnessing similar events and media in Europe and America, on the other hand also feeds the world with available information needed. Several studies focusing on women have been performed on the Arabian Peninsula, although information on gender studies are still scarce. It was first made public in November 2011at a conference in Cairo on gender 
transformations in the Peninsula of Arabia and the African horn. According to reports, women are gaining influence even though some are against their rights and inclusion. In the Arabian Peninsula, women's status is involved in local and international discussions to change their condition, even if the levels are not the same.

\subsection{Colonial Legacy and Development of Women Status in Egypt}

The early $20^{\text {th }}$ century saw females speaking and protesting colonial practices. During the 1919 revolt, women together with men were actively involved in the quest for freedom of Egypt. Nonetheless, when political leaders were given political rights in 1922, women were denied their political rights.

Comparing African countries, women, in particular, did not attain their status as men by default. To some, Women are inferior beings in African and even across the world, who are supposed to perform domestic duties. Egyptian women have had to work their way out of prejudices and societal roles. Women continue to demonstrate their power and advocate for equality with men on rights. The majority of Egyptian women played critical roles in Egypt's liberation from British rule and attainment of self-rule as a republic. Some women served in battles, while others were more involved in feeding their men. Women were also in charge of maintaining homes and caring for children at this time. The discourse on women began to shift at this stage and has continued to do so. Even though they continue to fight for gender equality, their position has been strengthened and respected (Megahed, and Lack, 2011).

\section{Problem Statement}

The role of women has changed drastically since the Arabian revolution. Many reports suggest that their status improved after colonialism. Others claim that during the colonial period, women's status declined, and it was only after the Arab rebellion that things began to change. The study seeks to determine women's role in ancient Egypt and after colonization against this backdrop. The focus is on the period 1952-2016, whether or not women in the Arab world, especially in Egypt, still end up as housewives despite having earned higher education during the globalization era.

\subsection{The Purpose of the Study is to:}

a. Discuss women's status during ancient Egypt and the post-colonial period.

b. Establish the influence of colonial legacy on women disparity from the period 1952 to 2016.

c. Establish the influence of colonial legacy on women disparity in the labour participation period, 1952 to 2016. 
d. Establish how the Arab revolt has contributed to the change of status of women in Egypt.

\subsection{Main Research Question}

How has Colonial Legacy and the Arabian Arab Revolt influenced the Social Status of Egyptian women in the period (1952-2016)?

\subsection{Specific Research Questions}

- What were the status of women during ancient Egypt and the post-colonial period?

- What has been the effect of the colonial legacy on females' disparities in education from (1952 to 2016)?

- What has been the influence of colonial legacy on females' disparity in access to labour in the period 1952-2016?

- How did the Arab revolt contribute to the social status of women in Egypt?

\subsection{The Significance of the Study}

To highlight Egyptian women's historical marginalization and how colonization was allegedly intended to emancipate women but ended up subjugating them. The research also provided academic data on how societies and social systems led to women's liberation before and after colonization. Furthermore, this study will be useful to researchers and policymakers in Egypt to boost women's modalities for developmental participation.

\section{Literature Review}

This brings up the issues of Colonial Legacy and the Evolution of the Social Status of Women in Egypt, from the period 1952 to 2016, and covers how colonial legacy affected their status. It investigates the impact of colonialism on social lives in general, spotlighting Egyptian women.

\subsection{Women Development in Egypt}

Looking at past contemporary theories, women's progress in Egypt differs in diverse ways. In the area of growth, Egyptian women were so different from women in any other African country. The ties between nationalist movements and modernization progressed amid secular and religious trends (Mostafa, 2003). In comparison to all other ancient cultures, Egypt is perhaps one of the few societies where the role of women in society is respected. They were interested in all layers of the social hierarchy. The most common occupation among lowincome women was that of a seamstress. The profession was the peasantry, which included a large number of other citizens. If the male members were unavailable, women were to conduct business. Egyptian women from middle-class families worked as perfumers and worked in temples or courts (Joubin, 2020). Women's work, such as dancing, singing, and acrobatics, was 
abundant even after British colonization. The British kings had noblewomen serving them. Lady Peseshet, for example, was a doctor in Ancient Egypt during the Fourth Dynasty. And during the colonial and post-colonial times, medication was being developed (Abugideiri, 2016).

Women made significant contributions to society during colonization. In addition, it was likely that women only occupied higher positions in society because of their religious convictions. The cultural and economic practices of Egypt changed drastically after 1882 when it was governed by the British. Various roles played by women in Egypt during the colonial era, both in ancient times and modern times, made an essential impact on society. They were in charge of household care, reproduction, and agriculture, among others. During the British conquest of Egypt, their rights, such as religious values and the right to education, were questioned. Under the Islamic faith and Arab nationalists, enslaved women became the typical victims of Egypt's conquerors. Under the influence of their Islamic religion, Arabs despised the creation, brain, future, and freedom of women (Yacoub, 2015); as a result, Egyptian women were not allowed to educate themselves. Women in ancient Egypt wove, mourned, and played music (Khalil, Arfa, El-Masrey, El-Sherbini, \& Abd-Elaziz, 2017).

Women's status was disrupted by the British invasion which hindered their freedom and this was supported by the conquerors from the United Kingdom. Again, their rights under Islamic family law, according to Younis (2006), continue to be a litmus test for challenging the rights God granted women in Islamic theology. Egyptian women who converted to Christianity had opportunities to engage in studies such as studying English as British missionaries brought Christianity to Egypt (Yacoub, 2015). Cleopatra, for example, was a woman ruler of Egypt before the British invasion (Jackson, Whipp, Gawthorpe, \& Lewis, 2019). However, women's aspirations were marginalized by colonialism, and their job was to nurture their children from the outset, educating them about gender roles and the socio-cultural environment. Women were not permitted to work in men's positions (Khalil et al., 2017). Women were tasked to perform domestic activities, and this marginalization caused a wave of resistance and protestors.

Various unions endorsed the women's movement at the time. This included the EFU (Egyptian Feminism Union) which supported the Feminism of the Pan-Arab movement of the 1930s and 1940s, which allowed intertwined Islamic modernism concerning Arabism. However, the leader or president, Huda Sha'rawi of the newly founded Arab Feminism Union (AFU) in 1944 in Al-Kashkul, a cartoon depicting Safiyya Hanim Zaghlul and Huda Hanim Sha'rawi by Egyptian police officers revealed that the British were not pro-feminism to consolidate a collaborative vision among Arab countries, the AFU, and the Arab Feminist 
Congress (AFC). Furthermore, they were encouraged to engage in global women's activism movement by their union. Egypt dissolved the EFU in 1956, decades after the Arab women's movement and the aftermath of the 1952 revolution. The EFU, on the other hand, used the name of a social welfare society, the Huda Sha'rawi Association, which is still active today (Doerr, 2014).

\subsection{Women During the Gamal Abdel Nasser Period (1956-1970 1st Period)}

This section gives an account of the occurrences during the Nasser regime. His reign saw feminist groups adopting his rules when laws were endorsed to incorporate Civil Society Organizations under national control. This led to a moment of 'State-Feminism', and this eventually changed Nasser's reign of power as a virtue of his "open-door economic policies"

Gamel Abdel Nasser ruled from 1956 to 1970. There was a remembrance of the scenario when a celeb actress Soad Hosni in Egyptian tried to persuade her male workmates on their vacation during the summer in the Mediterranean. She told them that house chores equally should be done among women and men. They did deny, but Hosni shouted in agony and said "Have you forgotten that we live in the era of equality?" This phrase was from an episode of the 1968 movie from "Marriage on the Modern Way" (Al-Zawaj 'ala al-Tariqa alHaditha). The demonstration of the movie displayed the wide gap between people who were the monarchy and those under modernization, born to view Egypt as an independent country. The movie director Sarah Karim needed to let her audience know that money should not be the price for a groom. That marriage should rely on the understanding of the ambitions of a couple and the compatibility of their education. When some women feminists persistently tried to request their rights of anguish, religious officials released a manifesto against equality.

The gender issues were resolved after two years giving men and women equal opportunities in the 1956 Egyptian constitution. Women from Egypt were then allowed to have voting rights. They voted during the initial election of parliament members after the 1952 revolution (Torunoglu-Selamet, Pamay, \& Eryigit, 2016). In the election, five women ran for positions in parliament whereby two of them won seats in parliament. Furthermore, in 1959, women were eligible for equal pensions and salaries as men, together with numerous rights on economic and social responsibilities. Also, Egypt, for the first time, admitted that women were supposed to act as a substantial role in the establishment of new post-colonial Egypt. A Charter of National Action established in 1962 by Nasser stated that "Women should be free from all social barriers". In that same year, Zeid Abu Hekmat was the first female minister in Egypt, who served as minister of social affairs. The latter showed that women were appointed as topranking university government workers and ambassadors. 
The development in the public sector has made several women work in different industries. For example, a new university on the outskirt of Cairo has promoted women's education. They took advantage of the 1954 administrative decree in which gifted students could pay fewer tuition fees: several female students enrolled in universities within Egypt. In the early 1960s, the number of female students was almost equal to that of male students in some faculties. Some women scored high qualifications enough to allow them to obtain their post-graduate degrees from abroad and Egypt.

In 1956, Megahed Horiya was the first female to achieve a $\mathrm{PhD}$ in political science academics. But such developments to encourage women's education had various limitations. Feminist Asmaa Halem documented in 1965, that the minister of labour had restricted women from participating in some jobs, for instance, working at wineries. The court of judges was a location where the traditional perception of the woman role from working in indigenous areas as the state withdrew from its social efforts during Nasser's era. There was the gradual acceptance of a free market economy in the 1970s; therefore, the concern for rights was insignificant led to the rise again, an upcoming strive to fight for Egyptian women. Nasser's biography documented by Bibliotheca Alexandrina indicates rising numbers of women in the 1960s who participated in the public sphere. Several women made claims for equal rights among all genders. These equal rights were granted under the realization that women could be of more assistance in building society.

\subsection{Women During Muhammad Anwar Sadat Period (1970-1981 2nd Period)}

During the Sadat period, economic associations between the Islamists and the state needs were initiated. They needed to use the conglomerate relationship to go against economic liberalization (Sidahmed, 2018). Between the early years of 1976 to 1981, there were several religious projects for the middle-class Egyptians of the 'Islamic Revival' in Egypt (RockSinger, 2015). There were letters to the editors and fatwa requests that differed in ideological reviews as indicated in the three Islamic magazines (Statist, Salafi-Islamist, and BrotherhoodIslamist). They produced a socio-economic and geographic classification of celeb individuals in these magazines.

In recent decade, the influence of the western media has continuously portrayed the veiled Muslim women as being oppressed. The media coverage fed us the interpretation of the veil as an irrefutable symbol of Muslim women seen as a symbol of subordination and servitude. In 1970, when Anwar el-Sadat gained power in Egypt, Egyptian women had been granted more presence in the public and social, intellectual, and standard experience to proceed with their activism under Sadat's regime. Sadat ruled as president from 1970-1981. At first, 
Sadat amalgamated his presidential power by vanquishing secular leftists and Nasserites and worked with the Muslims to achieve his goals. The alliance with Islamists increased the rivalry of Muslims that had exacerbated life for secular Democrats and women.

Women's equality statutes in 1971, were reversed. It was a significant setback on equality issued under Nasser's governance and permitted gender equality laws that did not demean the Shari'ah law rules. The Constitution of 1971 indicated that women were granted equality in their responsibilities to the family, societal work, and professions. However, in cultural spheres, social and political privileges were granted only if the work did not violate the Islamic Shari'ah law. Moreover, in the late 1970s, women's rights were encouraged by the Sadat regime for global relations reasons. Sadat's infitah “open door" laws and approaches with the United States were rhetorically strong as pro-Western. He continued to strive to accommodate a worldwide reputation as a modernizer and Westernizer; this role-play was to support the rights of women. Jihan Sadat, the wife of Sadat, encouraged uprising gender issues that put pressure on Egypt. Through the advocacy of rights of women and international feminist teams, she formed the UN Decade of Women that lasted from 1975 to 1985 . Her husband, Sadat also introduced the National Commission for Women and Egyptian Women's Organization (NCWEEO) to act on children's welfare, illiteracy, and family planning (Torunoglu-Selamet et al., 2016).

Jihan's law (Najjar, 1988), guaranteed a woman's licit rights in child custody, divorce, polygamy, and marriage and this was passed by parliament under a presidential decree. Despite 1979 Jihan laws in progress, Egypt, under Sadat's governance, did not promote independent feminist activism. The famous feminist like medical doctor Nawal al-Saadawi who wrote a book of "Women and Sex," 1971" was arrested in 1981 and imprisoned for months for defamation of character.

\subsection{Women During the Era of Hosni Mubarak (1981-2011 $3^{\text {rd }}$ Period)}

This period under Hosni Mubarak saw a great increase in females' rights groups but was also undermined by Islamists, militant groups and groups with staunch Islamic ideologies.

In 1981, a member of a Muslim militant group assassinated Sadat during a military parade that commemorated the Kippur Yom War in Cairo, Egypt. Vice President Hosni Mubarak became his successor. Hosni Mubarak's presidency lasted from 1981 to 2011. The growth of the Islamist movement in Egypt constitutes both an ideological and political struggle in the country. It also experienced massive opposition movements of the Muslim community in the past years. The Islamist groups in the country have had a history of exclusion, especially in matters of political power and particular government policies or ideologies. The neglect has 
resulted in them turning to violence as the right way of tackling the Egyptian regime since the 1970s. Their actions have taken on ways that are described as threats to the regime. The minuscule attempts made for political freedom have failed to quench the thirst for more serious recognition by the moderate Islamists. This was a common phenomenon, especially in the Sadat and Mubarak regimes. The regime also fell short of putting a stop to the growing militant activity (Sidahmed, 2018). In the early 1980s, the visibility and association of independent women activists were renewed and was generalized by competing discourses. It was during this time that Arab Women's Solidarity Association (AWSA) was formed. The association held a conference in 1986 with the slogan "Unveiling the Mind". They organized several women seminars to discuss their cultural issues, including the critical positions of Muslims regarding gender issues. Islamic women activists such as Heba Rauf Ezzat, Safinaz Qazim, and Zainab al-Ghazali encouraged conservative gender responsibilities that justified the virtues of motherhood and the family (Torunoglu-Selamet et al., 2016).

Under President Mubarak, scholars studying gender revealed that there was a rise in protests and the Islamists concerning the implementation of the Shari'a law. This confrontation put pressure on the regime of Mubarak. The protests wanted more traditional policies and laws towards women to be passed and amended, to end support for women representatives in the political system. Mubarak banned The Personal Status Law of 1979 and cancelled the refined laws under Sadat as several traditional and fundamentalist voices obtained significance. The impacts on EFU remained seeable after its revival in 2011 by Hoda Badran, who was the Arab Alliance for Women (AAW), on 25th January 2011, the day that was selected for large-scale protests in the capital's Tahrir Square. Osman, the 22-year-old chose to take advantage of the occasion to speak out of her anguish at the government. She stated that they are overwhelmed and tired of dictatorship. She also said that they were losing hopes and their dreams as youths. Women's presence at Tahrir Square was indicated as powerful as they were heard that day. Osman and other Egyptian women were united. They protested against the traditional social landscape where their rights to participate and engage in the public sphere were dictated (Ararat, El-Helaly, \& Shehata, 2017). They are considered to have played a critical role in AntiMubarak's protests.

During this era, the number of Islamist women feminists had already increased. They included Heba Rauf Ezzat, Safinaz Qazim, and Zainab al-Ghazali who participated in the fight against conservative gender roles. These roles reinforced women by virtue to participate only in the family and motherhood house responsibilities. These rivalry perceptions about the "women's question" cropped up during the politics of the Mubarak and Nasser regimes. Over 
time this led to a proliferation of feminism among women activists in the political system of Egypt. Eventually, as Mubarak was still in power, the governing body to improve the women's status, and the National Council of Women (NCW) were established in 2000. It also passed a Non-Governmental Organization (NGOs) law which gave power to The Ministry of Social Affairs to dissolve the Non-Governmental Organizations within Egypt.

\subsection{Women and the Egyptian Revolution}

This section highlights the roles women played during the revolution. The revolution gives an account of the 2011 riot from the women's viewpoint which was based on external interviews with women activists. They were downplayed regardless of their numerous efforts.

To merge scholars' findings who studied the role of Islamic females in a revolutionary viewpoint, the two groups provided a uniquely creative and literary providing with a way to view the take on women's participation, and the contribution to the revolts in Egypt and the Middle East (Mostafa, Abdel-Hamid, \& AlBagoury, 2015). Women's condition in Egypt was equally unpredictable. In the 2011 Egyptian revolution, women participated in unprecedented numbers, assuming out-of-place roles, and at times their numbers were much more than men (Biggs, Biggs, Dakos, Scholes, \& Schoon, 2011). Regardless of this contribution, their roles have been downplayed. A study carried out at Nottingham University (Harb, 2011), discovered that one of the most potent ways women participated in the events leading to the 2011 Egypt revolution was online conducted by (Khamis \& Vaughn, 2011). The 420. discovery was constantly online and offline activities of Egyptian women over the period that led to the uprising. This ushered in a new age in Egypt and the Arab world's feminism history. The Asma Mahfouz reputable journal of Professional Communication as one of the founding members of the April 6 movement, became a significant figure online, posting viral videos calling fellow Egyptians to join her in at the Tahir square on January 25th. Her online activism helped foster the revolution, especially in protest of National Police Day. The day was to commemorate 50 police officers who lost their lives in the 1952 revolution (Saddy, 2012).

According to news, women made up as many as half of the demonstrators in Tahir Square in the days leading up to Mubarak's resignation and the bulk of protestor participants. The New York Times even called Asma Mahfouz one of the most public faces of the uprising; (Zoepf, 2010). Men and women demonstrators lived together in the same tent and no one insulted or molested women, according to one of Egypt's most influential figureheads. They were in unison and demanded to have a secular form of government and parliament and that both men and women should be included (Zoepf, 2010). The mix-up helped to highlight the point El Saddawi made about the focus on women as citizens not to alienate them as feminists 
(Zoepf, 2010). Current studies investigate factors that impacted the resolve of so many Egyptian women to take part in the 2011 Egyptian revolution. From that time, Egyptian women after revolutionaries gained some respect in politics, society, and social spheres.

\subsection{Statistical Data on the Participation of Women in Politics}

This section also accounts for the statistics of women's participation at various levels. Around 2002 and 2008, there was no substantial change in the proportion of women on local councils. Females made most progress at the district level, but the villages made the least progress.

According to research, these disparities arise because districts are mostly situated in bigger urban areas, where societal rules are most tolerant of females' political involvement. According to a 2008 study by the National Council for Women (NCW), females aged 50 and beyond were most likely to show up in local assemblies (NCW). Just 14 per cent of all women elected to local councils were under the age of 40. (Conti, 2008). According to the NCW report, 73 per cent of local council members kept their government employment, which affected public expectations of accountability and openness. To add to this, there was decentralization which was supported in theory by the 1971 Constitution. However, it was never completely enforced. In the run-up to the 2011 Revolution, public discontent was caused by a great percentage of illiteracy, inadequate communal services as well as social structure and amenities. In the 2018 local elections, Article 180 of the 2014 Constitution mandated that women be allocated onequarter of the seats on the provincial council. If this criterion was met, Egypt's female representation in local government would have matched the OECD average of 25.7 per cent. See table 1.

Table 1: The 1983-2002 Representation of Women in Each Administrative Level

\begin{tabular}{|c|c|c|c|c|c|c|c|c|c|c|}
\hline Local Councils & $\begin{array}{l}1983 \\
\text { Total } \\
N^{\mathbf{o}} \\
\text { Wom: }\end{array}$ & $\%$ of & $\begin{array}{l}1988 \\
\text { Total } \\
\mathbf{N}^{\mathbf{0}} \\
\text { Woma }\end{array}$ & $\%$ of & $\begin{array}{l}1992 \\
\text { Total } \\
\mathbf{N}^{\circ} \\
\text { Wom: }\end{array}$ & $\% \quad$ of & $\begin{array}{l}1997 \\
\text { Total } \\
\mathbf{N}^{\mathbf{0}} \\
\text { Womar }\end{array}$ & $\%$ of & $\begin{array}{l}2002 \\
\text { Total } \\
\mathbf{N}^{\circ} \\
\text { Woma }\end{array}$ & $\%$ of \\
\hline Governorates & 1789 & $15 \%$ & 2436 & $5.6 \%$ & 2508 & $4.4 \%$ & 3172 & $3.2 \%$ & 3227 & $3.5 \%$ \\
\hline Districts & 6652 & $15.2 \%$ & 8752 & $1.8 \%$ & 9,834 & $4.4 \%$ & 12,707 & $1.0 \%$ & 12,969 & $4.5 \%$ \\
\hline Cities & 3254 & $11.0 \%$ & 3772 & $2.3 \%$ & 4112 & $1.3 \%$ & 5000 & $1.7 \%$ & 5,146 & $2.9 \%$ \\
\hline
\end{tabular}




\begin{tabular}{|c|c|c|c|c|c|c|c|c|c|c|}
\hline Neighbourhoods & 656 & $10.7 \%$ & 987 & $4.1 \%$ & 1018 & $3.7 \%$ & 1,254 & $4.5 \%$ & 1372 & $5.2 \%$ \\
\hline Villages & 15408 & 5.65 & 17,740 & $0.5 \%$ & 20160 & $0.6 \%$ & 25248 & $0.7 \%$ & 24922 & $1.3 \%$ \\
\hline Total & 27,768 & $9.2 \%$ & 33,678 & $1.5 \%$ & 37,632 & $1.2 \%$ & 47381 & $1.2 \%$ & 47636 & $1.8 \%$ \\
\hline
\end{tabular}

(Source: "Women in the locally elected councils", The National Council of Women, 2008)

\subsection{International Instruments and the Global State of Women}

Globally, women who get the opportunity to rise to the top leave a great legacy that affects their nations positively.

No country in the world can boldly boast of stability without the contribution of women. Their empowerment is the key to political stability, economic growth, social change, or transformation, which has led to the leaders of the world advocating for this crucial movement. Barack Obama said, "When women thrive, nations are more peaceful, stable, and prosperous" as referring to the quotes of Kofi Annan, the late UN Secretary-General, and Amartya Sen, agree that "empowering women is crucial to creating the future we want." So, then the big question is, why is this not reflecting on a bigger platform in most of our worlds, particularly in the MENA? Globally, the driving force (women) that change society, has been marginalized from time immemorial.

In 2016 and 2017, women's state in warring nations was nothing to write home about in the sense that, forty-eight women and girls were raped hourly in the Democratic Republic of Congo capital, while in South Africa, two girls were raped every minute, three women eliminated every day in the United States of America. In the public sectors, women were being discriminated against in employment, decision-making, education, owning properties, etc. either by race or for being a woman. Again, in the second and third world, of which the MENA countries are no exception, it is cultural-based discrimination, women's voices are not heard at all for these diverse reasons. However, among the various international and regional instruments drawn to address human rights issues is the United Nations Convention on the Elimination of All Forms of Discrimination against Women (CEDAW) which was adopted in 1979 by the United Nations, to see to it that women are free from all kinds of violence and discriminations. It is essential because it regards the rights of females as human rights and 
seeks to give the framework for achieving gender equality by ensuring that women have equal access to rights in political and public life, as well as schooling, employment, and health care. CEDAW is the only international treaty that has been ratified by 193 nations, making it one of the most commonly ratified treaties on the planet.

The question here again is, if CEDAW has come to stay and to seek the welfare of their rights respected, why then the continuous discrimination against women in most regions of the world? Could it be that member states only sign treaties to register their membership or just paperwork for the world to see that there is an organ that seeks the wellbeing of women but also refuses to practice what has been documented? Women's rights were perceived in the Universal Human Rights for the formation of the human rights constitution that women were not receiving their human rights without special consideration, the situation shifted. Nonetheless, most women, especially in Africa, are confronted with issues relating to their legal status under international treaties and customary law. Though CEDAW members have signed and ratified international treaties into their national law, some states continue to adhere to the law that does not identify certain rights, there are still gaps among policy as well as its implementation ratification, which has not been adapted into revised rights for women. Another instrument that seeks to address the wellbeing of women is the Commission on the Status of Women passed in 1946 under Resolution 2/11 of the UN Economic and Social Council. The council unit charged responsibility of female rights in the economic, political, social, civil, and educational fields, making recommendations on reports of pressing issues about women's rights discipline. This Commission has advocated for women's rights right from its inception, they give governments, international bodies, civil society, and stakeholders solid recommendations, throughout history to promote women's rights and are actively playing its role in landmarks global legal and policy instruments like CEDAW, The Beijing Declaration and Forum for Action, in addition to the Declaration on the Elimination of Violence Against Women. If all these international instruments exist and are actively working, why are women marginalized in certain areas of life? (Eniola \& Omoleye, 2018).

\section{Conclusion}

Egypt and North African nations linked to Middle East Arab culture, common language, and religion, also by a shared battle for freedom and the resurrection of "Islamic" principles, Arab culture. The contemporary study of gender inequality and females' rights in Egypt is framed by the interaction of creeds that have shaped gender equity and rights in Arab Muslimmajority cultures, particularly in Egypt. 
The author compared "Islamic" teachings and local customs to Western, European colonial notions of females' rights including social practice. In addition, the study looked at how national governments responded to international pressure by implementing genderfocused reform programs. Egypt highlights the parallels and contrasts in the respective genderrelated reform programs, the clash within the traditional and continuous ideas that existed in the country, throughout their gender-related reform policies. The opposing forces impeding the reform programs are the colonial legacy and Western perceptions of Muslim women - who are seen as oppressed, relegated to the back, and exempted from the world. Egypt has vigorously modified women's status and family law, carefully improving public position and civil rights. Egypt was a protectorate, unlike other Arab countries, with French or European involvement. As a result, opposition to its gender-related change was less linked to a colonial, Western view of modernization.

Nonetheless, to carry out reform goals, the governments of northern African countries banned all religious groups and advocated a "modernistic interpretation" of Islamic law. Egypt, on the other hand, had faced pushback from various "Islamic" groups to its gender-related changes. Despite legislative reforms, the conflict between fundamentalists and the government has remained. Fundamentalist parties, local authorities, the global society had all backed female education in the Arab world, recognizing the dual function of schooling as a force for reform and or perpetuation. Egypt has achieved universal education access and has significantly narrowed the gender gap. Notwithstanding, there are still inequalities in higher education, and gender equity is yet to be attained in Egypt and a few North African countries.

\subsection{Scope of Future Research and Limitations}

The main purpose of this research is to analyse how Colonial Legacy and the Arabian Arab Revolt has influenced the Social Status of Egyptian women from 1952 through 2016. This is an archival case study, using the women of Egypt, and to analyse whether there has been a great improvement in the social life of women of Egypt. What informed this research was the historical marginalization and how colonization was allegedly intended to emancipate women but ended up subjugating them.

The study area is Egypt, and it is intended to be completed within the space of one year which is almost in completion. This research used the qualitative method to explain and analyse the data that were collected. This study made use of secondary data solely, from books, publications, journals, useful websites and other sources that were useful. This was due to one major challenge, which was the inability to be at the study area to collect primary data due to the world's pandemic (Covid-19) which brought lot of restrictions on movements, hence the 
need to resort to secondary data only, to analyse, compare and contrast what the changes that have occurred over the years. Although this research was limited to some extent, it does not make it irrelevant because the data and facts have been collected from relevant source which makes it equally useful for other works.

\section{REFERENCES}

Abugideiri, H. (2016). Gender and The Making of Modern Medicine in Colonial Egypt: Routledge. https://doi.org/10.4324/9781315583990

Allam, Z., \& Newman, P. (2018). Redefining the Smart City: Culture, Metabolism and Governance. Smart Cities, 1(1), 4-25. https://doi.org/10.4324/9781315583990

Amar, P. (2011). Middle East Masculinity Studies: Discourses of Men in Crises," Industries of Gender in Revolution. Journal of Middle East Women's Studies, 7(3), 36-70. https://doi.org/10.4324/9781315583990

Ararat, M., El-Helaly, M., \& Shehata, N. F. (2017). Boards' Gender Diversity and Firm Performance Before and After the Egyptian Revolution. https://doi.org/10.4324/9781315583990

Assmann, J. (2003). The Mind of Egypt: History and Meaning in The Time of The Pharaohs: Harvard University Press.

Beck, J., Jenks, C., Keddie, N., \& Young, M. (1979). Worlds Apart: Readings for A Sociology of Education. British Journal of Educational Studies, 27(1). https://doi.org/10.4324/9781315583990

Berman, Y., Shapira, Y., \& Ben-Jacob, E. (2015). Modelling the Origin and Possible Control of The Wealth Inequality Surge. PloS one, 10(6), e0130181. https://doi.org/10.4324/9781315583990

Biggs, D., Biggs, R., Dakos, V., Scholes, R. J., \& Schoon, M. (2011). Are We Entering an Era of Concatenated Global Crises? Ecology and Society, 16(2). https://doi.org/10.4324/9781315583990

Conti, E. (2008). Political Rights and Representation for Women in Egypt. Wahbi, Azza. "Women in The Locally Elected Councils", The National Council of Women, 2008.

Comer, D. C. (2012). Tourism and Archaeological Heritage Management at Petra: Springer. https://doi.org/10.4324/9781315583990

Campbell, N. D., \& Rogers, T. M. (2007). Economic Freedom and Net Business Formation. Cato J., 27, 23. 
Crippa, P., \& Cucut, C. (2020). The Divisions of The Army of The RSI 1934-1945 (Vol. 11): Soldiershop Publishing.

Doerr, N. (2014). Memory and Culture in Social Movements. In Conceptualizing Culture in Social Movement Research (pp. 206-226). Palgrave Macmillan, London. https://doi.org/10.1057/9781137385796_10 https://doi.org/10.1057/9781137385796.0017

El-Safty, M. (2004). Women in Egypt: Islamic Rights Versus Cultural Practice. Sex Roles, 51(5), 273-281. https://doi.org/10.1023/B:SERS.0000046611.31760.04

Eniola, B. O., \& Omoleye, B. O. (2018). Baby Making Factories and The Reproductive Health Rights of Women in Nigeria. JL Policy \& Globalization, 72, 22.

Harb, Z. (2011). Arab Revolutions and The Social Media Effect. M/C Journal, 14(2). https://doi.org/10.5204/mcj.364

Htun, M., \& Weldon, S. L. (2018). The Logics of Gender Justice: State Action on Women's Rights Around the World: Cambridge University Press. https://doi.org/10.1017/9781108277891

Jackson, C. A.-L., Whipp, P. S., Gawthorpe, R. L., \& Lewis, M. M. (2019). Structure and Kinematics of An Extensional Growth Fold, Hadahid Fault System, Suez Rift, Egypt. https://doi.org/10.1017/9781108277891

Jacob, W. C. (2011). Working Out Egypt: Duke University Press. https://doi.org/10.1515/9780822391678

Joubin, R. (2020). The Multifarious Lives of the Sixth 'Abbasid Caliph Muhammad al-Amin: Collective Memory Construction, Queer Spaces, and Historical Television Drama in Egypt and Syria. International Journal of Middle East Studies, 52(4), 643-663. https://doi.org/10.1515/9780822391678

Kemp, B. J. (2018). Ancient Egypt: Anatomy of a civilization: Routledge. https://doi.org/10.1515/9780822391678

Khalil, H., Arfa, M., El-Masrey, S., El-Sherbini, S. M., \& Abd-Elaziz, A. A. (2017). Single Nucleotide Polymorphisms of Interleukins Associated with Hepatitis C Virus Infection in Egypt. The Journal of Infection in Developing Countries, 11(03), 261268. https://doi.org/10.1515/9780822391678

Khamis, S., \& Vaughn, K. (2011). Cyberactivism in the Egyptian revolution: How Civic Engagement and Citizen Journalism Tilted the Balance. Arab Media and Society, $14(3), 1-25$. 
Mahmood, S. (2015). The Religious Difference in A Secular Age: Princeton University Press. https://doi.org/10.1515/9780822391678

Marshall, K. (2008). The World Bank: From Reconstruction to Development to Equity: Routledge.

Megahed, N., \& Lack, S. (2011). Colonial Legacy, Women's Rights and Gender-Educational Inequality in The Arab World with Particular Reference to Egypt And Tunisia. International Review of Education, 57(3), 397-418. https://doi.org/10.1515/9780822391678

Mikhail, A. (2011). Nature and Empire in Ottoman Egypt: An Environmental History: Cambridge University Press.

Mostafa, M. M. (2003). Attitudes Towards Women Who Work in Egypt. Women in Management Review. https://doi.org/10.1108/09649420310485096

Mostafa, N. S., Abdel-Hamid, M. A., \& AlBagoury, L. S. (2015). Work-Related Respiratory Disorders Among Street Sweepers in Cairo, Egypt, A Comparative Study. Egyptian Journal of Community Medicine, 33(2). https://doi.org/10.1108/09649420310485096

Najjar, F. M. (1988). Egypt's Laws of Personal Status. Arab Studies Quarterly, 319-344.

O’Donnell, P. S., Abu-Lughod, L., \& Abu-Rabia, A. The Bedouin: An Introductory Bibliography.

Rock-Singer, A. (2015). A Pious Public: Islamic Magazines and Revival in Egypt, 19761981. British Journal of Middle Eastern Studies, 42(4), 427-446. https://doi.org/10.1080/13530194.2014.1002387

Saddy, R. (2012). Social Media Revolutions. Journal of Professional Communication. https://doi.org/10.1080/13530194.2014.1002387

Sezgin, Y. (2013). Human Rights Under State-Enforced Religious Family Laws in Israel, Egypt And India: Cambridge University Press. https://doi.org/10.1080/13530194.2014.1002387

Shaw, I. (2003). The Oxford History of Ancient Egypt: Oxford University Press.

Sidahmed, A. S. (2018). Islamic fundamentalism: Routledge. https://doi.org/10.1080/13530194.2014.1002387

Tucker, J. E. (1985). Women in Nineteenth-Century Egypt (No. 7). Cambridge University Press. https://doi.org/10.1080/13530194.2014.1002387

Torunoglu-Selamet, D., Pamay, T., \& Eryigit, G. (2016). Simplification of Turkish Sentences. Paper Presented at The First International Conference on Turkic Computational Linguistics. 
Tyldesley, J. (2012). Tutankhamen: The Search for an Egyptian King: Basic Books (AZ). Yacoub, M. (2015). The Diglossic Situation of Arabic Language in Egypt: Is Low Variety Planned to Get Standardized. International Journal of Social Science and Humanities Research, 3(1), 382-387.

Younis, M. (2006). Daughters of the Nile: The Evolution of Feminism in Egypt. Wash. \& Lee J. Civil Rts. \& Soc. Just., 13, 463.

Zoepf, K. (2010). Talk of Women's Rights Divides Saudi Arabia. The New York Times. 